\title{
JCN Journal of Clinical Nursing
}

\section{Indian nurses in Italy: A qualitative study of their professional and social integration}

\begin{tabular}{|r|l|}
\hline Journal: & Journal of Clinical Nursing \\
\hline Manuscript ID & JCN-2016-1370 \\
\hline Manuscript Type: & Original Article \\
\hline Keywords: & $\begin{array}{l}\text { Content Analysis, Cultural Issues, Ethnicity, Nurses, Qualitative Study, } \\
\text { Multicultural Issues }\end{array}$ \\
\hline \multicolumn{2}{|c}{} \\
\hline
\end{tabular}

SCHOLARONE ${ }^{m}$

Manuscripts 


\section{Introduction}

Since the end of the 1990s Italy has had to hire nurses from overseas to fill nursing shortages. The Italian authorities had not enough existing supportive policies to fulfill the needs of its healthcare system. In 2008-2009 a nursing workforce of 10.2\% of internationally educated nurses (IENs) from different geographical regions were active in Italy, mainly from Romania, Albania, India, Peru, Poland, and other European countries (available at: http://www.ipasvi.it/ecm/rivistalinfermiere/rivista-linfermiere-page-7-articolo-84.htm). To date, the ratio of foreign nurses at a national level is greatly reduced (available at: http://www.ipasvi.it/ecm/rivista-linfermiere/rivistalinfermiere-page-16-articolo-193.htm). Italy and other southern European countries (Spain, Portugal, Greece), have become nurse emigrant countries more than nurse immigrant countries (Correia et al. 2013, Ribeiro et al. 2014). However, in the changing scenario, and in a context of a slowing down of nurse immigration to Italy because of the economic restraints suffered in the last years, the inflow to Italy of Indian nurses is steady,especially in large urban areas. Malayalee nurses (Indians from the southern state of Kerala), have been showing an increasing interest in coming to Italy.

\section{Background}

To study the global nursing flux is a health priority in the globalized world (Tschudin \& Davis 2008). The growth in migration trends among nurses, not only from the Philippines or India, has proliferated in recent years (Pittman et al. 2007, Garner et al. 2015). This has been attributed to the increased global demand for nurses and the rising aged population in industrialized countries. This has subsequently produced a growth in international recruitment efforts. The increased migration of 
nurses from the Indian southern states of Andhra Pradesh, Karnataka, Kerala, and Tamil Nadu has also encouraged the increase of nursing schools in those areas. These same states have $63 \%$ of the general nursing colleges in the country, 95\% of which are private, (Rao et al. 2011; Evans et al. 2013; Walton-Roberts 2015). Especially Kerala, in the southern part of India, is known for its Catholic tradition and has become a nurse supplier to Italy. In Italy and, particularly in the great urban areas of Rome and Milan, Malayalee women have traditionally been employed in domestic service and in healthcare (Gallo 2006). The Keralan migrants in Italy have always been embedded in the network of the Catholic Church. A Roman Catholic destination has traditionally been judged a culturally correct choice for Catholic women who were brought up in a mainly patriarchal society (Lum, 2012). Young Malayalee nurses were stimulated by the examples of relatives or friends who first came to Italy from the late 1960 s to the 1980 s and who were successful in their employments, with consequent good remunerations to send to India as remittances (Gallo 2005; Gallo 2006).

In the past the main destinations for migrating Indian nurses were the Gulf countries (Percot 2006; Lum 2012). However, this was essentially a circular migration, with nurses returning to India after working abroad for some years. Since the year 2000, new markets have been opened up for Indian nurses, e.g. the possibility of migrating on a permanent basis was facilitated by their kin networks in industrialized countries such as Australia (Kodoth \& Jacob 2013), Canada (Blythe \& Baumann 2009), New Zealand (Woodbridge \& Bland 2010), UK (Alonso-Garbayo \& Maben 2009), USA (Spetz et al. 2014) and western Europe (Kodoth \& Jacob 2013). One of these countries was Italy. Since 2008, there was an increase in Malayalee nurses coming to Italy and in the greater Rome area in particular, mainly with the indirect support of the Catholic Church (Authors 2015).

Yet, although Italy seems an increasingly popular destination for Keralan nurses, these same professionals also want to migrate to more attractive places such as Australia, Canada, USA, UK. This trend introduces the challenges of transitioning to a new health care culture, where nurses can 
experience high levels of distress requiring a long period of adjustment to the new society (Li et al. 2014).

The transitioning phase can last for years and full integration in the host country is sometimes difficult to achieve for different reasons, yet often for the existence of subtle manifestations of veiled employment discrimination (Dicicco-Bloom 2004, Pololi et al. 2010, Xiao et al. 2014). Hence, the flow of Indian nurses' out-migration is very complicated and goes beyond traditional migration theories of push-and-pull factors. In fact, the interconnections of political and economic reasons that are at the ground of the migratory processes of nurses have to be analysed in-depth in the ever-changing global trajectories to have a bigger picture of the phenomenon under scrutiny.

The Italian Nursing Regulatory Board IPASVI (Professional nurses, health assistants and paediatric nurses) gives strong organisational support to IENs, which is a factor that plays a large role in the Italian nursing scene.

It is in this light that this study was undertaken: to identify the experiences of professional and social integration of the Indian nurses' community in Italy linked to their wider social and political trends and movements.

\section{Study aim}

To develop greater understanding of the lived subjective experiences of immigrant Indian nurses in Italy and specifically their professional and social integration.

To explore their intra- and inter-professional relationships at work, the perception of the IPASVI Nursing Regulatory Board and their initial education and continuous professional development.

\section{METHODS}




\section{Study Design}

A descriptive qualitative design was adopted as a research strategy. In this study we used an inductive approach through single in-depth interview data collection to allow insights to emerge concerning the professional and social integration of Indian nurses in Italy.

\section{Sample characteristics}

This study drew on in-depth interviews with 20 nurses of Indian origin. Nurses in our purposive non-probability sample worked mainly in private hospitals and consisted of Italian and Malayalamspeaking, either Syrian-Orthodox or Roman Catholic Indian nurses.

The sample comprised men and women and a range of ages to maximize the representation of diversities (Polit \& Beck 2011).

The eligibility criteria for participation in the study included the following: (i) nurses 18 years and older, (ii) working in Italy for more than one year, (iii) ability to speak Italian. Participants were recruited on a voluntary basis. (place Table 1 here).

\section{Data collection}

Detailed face-to-face interviews with the participants were conducted by the investigators between April 2013 and March 2014. Interviews were led in Italian at a mutually convenient place and time, usually at the IPASVI Nursing Board Headquarters in Rome, using a semi-structured interview guide. Field notes were also taken of the nonverbal communication of participants. The interviews were recorded on a digital recorder, with each one lasting 20 to 60 minutes. 
The structured interviews were divided into four main parts:

- Aspects of professional integration (the working experience in Italy, the structure of the work, and the working conditions, such as the working contract).

- The nurses' intra- and inter-professional relationships and their perception of what IPASVI represents for them.

- The nurses' initial nursing education and their continuous professional development in Italy.

- The dimensions of social and personal integration, the relationships with the Indian community and the perceptions of their conditions of life.

\section{Data analysis}

All interviews were transcribed verbatim and hand-coded line by line by the study investigators. To increase the validity and the reliability of this study, the researchers took field notes during the interviews. Following this, three researchers (AS, LS, YTD) independently coded the transcribed material to test the emerging understandings of the data, and after two or three interviews, researchers discussed the interviews. Lastly, the researchers grouped meaning units with similar significance into categories and themes in agreement with the main areas delineated in the interview guide.

The data collected were coded using an inductive content analysis extracting meaning units from the information retrieved, following the process of content analysis by Granheim \& Lundman (2004). The transcripts were manually analyzed independently by the researchers, but the decision on categories and themes was made with the consensus of all the researchers concerned. The transcribed meaning units reflected the Indian nurses' perceptions about their professional and social integration in the Italian setting and constituted the manifest content (Saldańa 2009). The 
development of inferred interpretations that went beyond the content of original segments of data emerged through abstraction and were contextualized to the data (Mirza et al. 2014).

\section{Rigour}

To ensure rigour in the descriptions of Indian nurses' professional and social integration we employed the principles of credibility, dependability, confirmability and transferability developed by Lincoln and Guba (1985). Credibility was established by accurate purposive sampling of nurses and prolonged engagement with them. Meeting the dependability criterion is always spiky in qualitative designs, although researchers should at least strive to enable future investigators to replicate the study. With this logic, dependability was assured by the stability of the data collected between March 2013 and April 2014. Confirmability, which indicates the potential correspondence that data accurately reproduce the information that the participants provide, was accomplished by discussions among the research team. Transferability was assured by the various working experiences in different parts of Italy by the Indian nurses interviewed. A member of the research group who was skilled in qualitative research and who had neither participated in the interviews nor in prior analysis read the original un-coded transcripts to validate the results.

\section{Ethical considerations}

Permission to carry out this study was obtained from each participant at the beginning of the interview.

During the interviews, emotional support was provided to participants who became expressively overwhelmed for as long as they needed. To protect their privacy, participants were assigned a 
serial number each. The principles of autonomy, confidentiality, and anonymity of information were followed throughout the study.

\section{RESULTS}

\section{Aspects of professional integration and working experience}

The main motivation to emigrate was a push economic logic with higher pay and better working conditions. According to the majority of the nurses interviewed, they did not take up nursing as a vocational choice, but to find a job in India and in the global North countries.

The choice to travel to Italy was often made for reasons of family reunification and was facilitated by the interceding contacts, in part by the Catholic Church.

All the Indian nurses judged the out-migration experience in Italy as positive, but in the current economic turmoil in Italy, none of them would advise their relatives and friends to come to Italy to work as nurses:

As it is now, I would tell them [other Indian nurses] not to come to Italy. Many of them are asking me, but I discourage them and I explain to them that the economic situation is difficult and they would have many privations for not much of a better salary. [Interviewee I04]

In the wider sense, nurses in Italy are experiencing difficult work situations because of work overload or as salary reductions. However, the Indian nurses seemed to accept this aspect more easily: 
There is more work to do now on the same contract conditions. They [employers] do not pay us overtime any more, but it is OK like this. At least we have work and this is important. [Interviewee I08]

From the interviews we could not perceive any overt episodes of discrimination in the care environment. However, some nurses assumed that Italian nurses perhaps experienced discrimination because they were seen by the employers as less adaptable to work overload with poor staff ratios and hard shifts rotations:

For the time being, they [employers] go on hiring foreign nurses; we have many Romanian nurses. If they are good they are hired and they work. Everything depends on how you are committed to work. You are assessed on your willingness to perform a good job and not on other situations. [Interviewee I05]

The perception of an Indian nurse regarding young Italian nurses was interesting:

Many young Italian nurses, just graduated, started to work on this ward, but almost all of them left after a month or so, because here [where the Indian nurse was working] there is a great work overload and the job is very demanding. [Interviewee I08]

\section{Intra- and inter-professional relationships and perceptions of IPASVI}

The interviewees did not report episodes of ethnocentrism from Italian nurses (occasionally they felt denigrated by Romanian colleagues). Some problems, not connected to their ethnic origin but linked to the different roles performed in the healthcare arena were encountered with physicians and 
healthcare assistants who sometimes showed little collaboration. However, this was a problem encountered also by Italian nurses in other studies. In such situations, the attitude of the Indian nurses was to avoid any debates and simply carry on with their work. An Indian nurse thought:

With physicians, the relationships are not always easy, these [physicians] don't figure out our professional skills and our professional autonomy. They don't recognize that we [nurses] are taking care of patients 24 hours per day and we know, more than they do, about the real clinical situation. [Interviewee I12]

A common element of the lived experiences of the Indian nurses was their clear perception that they did not have chances for career advancement. None of the nurses interviewed had organizational responsibilities and they were often underemployed and restricted in their scope of practice:

... Here $90 \%$ of the work is part of a healthcare assistant's duty, just for the remaining $10 \%$ I can claim that I'm working as a nurse. [Interviewee I02]

The nurses showed only a marginal knowledge of the IPASVI Regulatory Nursing Board and its mission. The respondents' experience of IPASVI was often restricted to the registration process, and to some extent the majority of the nurses completely ignored the organizational opportunities offered by IPASVI for free continuous professional education and all the other services available, such as lawyers for legal controversies, or the possibility to have free digital databases to browse through for updates. Many of the nurses interviewed interpreted IPASVI as a place to turn to if they had faced serious professional problems. The Regulatory Board was seen as a union more than a 
place designed to protect the citizens. Not uncommonly, among similar expressions, an Indian nurse commented:

I have never ever had problems at work so I never turned to the Regulatory Board. [Interviewee I08]

and another Indian nurse claimed:

The IPASVI could be useful to find jobs. [Interviewee I05]

The nurses who knew a little more about IPASVI almost unanimously complained about the difficulty to receive adequate information of the courses offered for continuous professional development. One Indian nurse asserted:

When you look at the IPASVI website there is a course with 25/30 places free, you try to subscribe and you always discover that it is already full. The IPASVI should offer more courses and give correct and up-to-date information about them. [Interviewee I08]

Many Indian nurses thought that a major commitment on the part of IPASVI was to be directed to learning the Italian language. They would particularly have appreciated a professional Italian language course for foreign nurses, which could facilitate their understanding of the main technical terms used. Verbal communication is a real barrier for Indian nurses who have significant problems with integration, because of understanding and speaking the Italian language: 
These Italian language courses could be a blessing for us because we would be able to get competencies in speaking and comprehension. [Interviewee I02]

\title{
Initial nursing education and continuous professional development
}

\begin{abstract}
All but six of the nurses interviewed received their first nursing education and training in India. They widely judged their nursing education in India as excellent. Above all, Indian nurses appreciated the internship and the long mandatory clinical placements that they had to attend because of the attentive and devoted mentorship.

Regarding her clinical education in Kerala, one nurse affirmed:
\end{abstract}

I had a clinical mentor who followed me all the time, especially during my different placements. [Interviewee I01]

and she continued:

... When I meet nursing students here in Italy, and they are in their clinical training in my healthcare organization, I have the impression they are left to themselves. [Interviewee I01]

The majority of the interviewees had only attained the minimum continuous professional development requirements to gain the number of credits every year. The reasons given for this comportment were time restraints: 
Now the work is always too much and in the little time left, I have to take care of my family. [Interviewee I09].

\begin{abstract}
Almost all the Indian nurses interviewed asserted that the educational courses were expensive, especially the post-qualification courses offered by universities were considered incredibly highly priced. Only two Indian nurses out of 20 attended a post-basic course by Italian universities. However, many of the nurses interviewed felt the necessity to be regularly updated on different healthcare issues. In this regard, a nurse argued:
\end{abstract}

In that ward we (healthcare personnel) only communicate electronically and I have severe problems with this because of a lack of knowledge of digital means of communication. Luckily, I have many colleagues who are helping me out. [Interviewee I04]

\title{
Perceptions of social integration
}

A large number of the respondents affirmed a desire to return to their country of origin. One of the pivotal reasons for this was not based on the worsening job conditions, but rather because of the lack of perspectives for their children. They claimed that the education offered at public schools in Italy was mainly mediocre. The majority of the Keralan nurses judged the Italian education system critically because classes were only taught in Italian. An interviewee stated:

If you only study in Italian you cannot go around the world and find a decent job. [Interviewee I09] 
Most of the nurses interviewed considered their processes of socialization as good enough as they wished to remain "foreigners". Their relationships were kept strictly to the family or the Indian community.

The Indian community is usually financially well included in Italy, but socially it is different. Indian social life ranges around family and Indian contacts. This is different for their children who, due to the acquaintances in schools or in parishes, join and get easily familiar with Italian children.

One nurse stated:

My children have experiences with youth organizations such as boy scouts; they have friends, they go out with Italian mates, they have no problems ... they are very well integrated [Interviewee I04].

Few episodes of social discrimination outside the workplace came to light in the interviews. Indian nurses were rarely denigrated, though sometimes they overheard that they were blamed by the Italian community for stealing work opportunities from Italian citizens. Fortunately, it seemed that these occurrences were not frequent, as recalled by this nurse:

... Because I have a brown skin I have had some encounters with uneducated people in the streets or in the shops, such as verbal aggression by ignorant persons. This is not a common behavior by Italians or more widely in society. They are just people without logic. [Interviewee I20].

\section{Discussion}

The main themes that came to light from the in-depth interviews (Place Figure 1 here) 
Aspects of professional integration and working experience

This is the first study in Italy that considers issues for and of nurse migration from India. Nurse migration is a complex issue in our globalized world, with sudden changes in flows in relatively short periods of time (Prescott \& Nichter 2014). It is also the first research that highlights a particular situation that has taken place in recent years in Italy because of the hard economic recession suffered, and which has been causing a shift in nurse migration patterns. Italy is now both a nurse emigrant country and one that attracts nurses, particularly from Romania, India, Albania, etc.) (place Table 2 here).

In the context of global mobility, the interpretation of the professional experiences lived by Indian nurses in Italy was important to study the elements that facilitated their integration and their cultural socialization.

Indian nurses have a long history of looking for overseas opportunities (Gill 2011, Johnson et al. 2014) because of unsatisfactory working conditions at home (Alonso-Garbayo \& Maben 2009, Johnson et al. 2014, Nair 2012, Rao et al. 2013), low salaries and a poor image of nursing, often linked to a masculine and patriarchal society (Gallo 2006, Nair 2012, Walton-Roberts 2012, Johnson et al. 2014). In this setting, while nursing in India remains a predominantly female profession, the perceived employment opportunities for male nurses have resulted in an increased demand for nursing qualifications among young men, especially in the Christian community (Evans et al. 2013, Kodoth \& Jacob 2013). This could be detected in our sample where the majority of the Indian nurses interviewed were women, but about one-third were men.

All the Indian nurses interviewed judged their experience in Italy positively, adapting to a new professional culture even in the difficult situation of the economic restraints of the last years. However, many of the respondents would not advise their peers to come to Italy to work as nurses 
for different reasons: big difficulties in finding a suitable and well salaried nursing job, major work overload at work and a declining salary compared with higher incomes that could be gained in more affluent countries (Australia, Canada, USA, UK, etc.).

Intra- and inter-professional relationships and perceptions of the IPASVI Regulatory Nursing Board

To evaluate the professional integration, the intra- and inter-relationships with other healthcare professionals and their attitudes towards work are pivotal.

In the work settings experienced by the Indian nurses interviewed, some occurrences of unfairness were reported. However these events seemed not to relate to any ethnic origin. In countries like Italy, where physicians still have a strong dominant position, especially in hospitals and nursing homes, this is not only a problem for Indian nurses; almost all nurses are limited in clinical autonomy and decision-making (Sabatino et al. 2016).

These historical, social and cultural positions of nursing and medicine in Southern European countries are expressed by rigid disciplinary boundaries that tend to maintain historical hierarchies and impede the development of constructive relationships (Price et al. 2014). These circumstances are therefore major features to be taken into account when discussing the ethnicity of the nurses interviewed. As stated by Allan (2016), perhaps racist habits stem from 'unreflective practices in an increasingly unstable and busy working environment' (early view on line) more than from open behaviours of discrimination. In our study it was evident that Indian nurses had good relationships with other Italian or foreign nurse colleagues and peers rarely discriminated against them, at least overtly. 
Some Indian nurses underlined that the relationships with physicians were sometimes controversial, especially about the recognition of professional competencies and clinical autonomy (Ma et al. 2010, Sabatino et al. 2016). Healthcare assistants also contributed to a hostile work setting and exhibited attitudes of lack of regard, avoidance, and rejection of duties. Indian nurses claimed that although the collaboration with support workers was crucial to focus on their scope of practice and to have better teamwork, this dimension of the job was lacking from time to time because of disengagement behaviours by some of them (Fida et al. 2016).

Attitudes of indifference and aversion were sometimes shown by older nurses because of the changes that younger colleagues brought with them by maintaining evidence-based practice in everyday work. This is in line with other studies that highlight that this attitude of lack of respect is not due to racism by peers and employers, but is more connected to cultural mindsets and to the evolution of the nursing profession (Rocco et al. 2014).

When very rare episodes of discrimination took place, Indian nurses always coped with them by ignoring the biased behaviours. In our analysis, the unfairness experienced by the Indian nurses was not as common as in other studies (Beechinor \& Fitzpatrick 2008; Jose et al. 2008; Jose 2011).

None of the Indian nurses had roles of responsibility. Fewer opportunities for career advancements are common in many emigrating countries for IENs and the nurses interviewed complained about the lack of prospects for upward mobility (Allan 2016, Kodoth \& Jacob 2013, Humphries et al. 2015, Timilsina Bandhari et al. 2014, Xiao et al. 2014).

The IPASVI Nursing Board as an institution has as its main mission to exert discipline, opposing abuse and being sure that nurses comply with their code of ethics. This was often misinterpreted by the interviewees as they did not understand its real task. In fact, almost all the Indian nurses interviewed did not know its real functions, mission and general objectives. They often believed that the IPASVI had as its primary role to promote and protect nurses and the nursing profession. Only very few nurses knew the real significance of a regulatory Board. 


\section{Initial education and life-long learning}

The majority of the nurses interviewed gained their basic nursing education in India. The educational courses followed in the source country were deemed satisfying and some of the interviewees also expressed the opinion, having seen the Italian nursing bachelor students during their clinical placements, that the nursing education in India had to be considered to be of a high standard. These findings differ from some trends that emerged in the Southern States of India in the last years where private and unrecognized and unregistered nursing schools cropped up to meet the demand of nurses for the global market (Rao et al. 2011, Johnson et al. 2014, Walton-Roberts 2015).

The requirement for continuous professional development of the Indian nurses interviewed was the same as the Italian rules for life-long learning.

Indian nurses were very concerned with the costs of the educational courses they could attend and preferred to participate in educational events offered for free, whatever the scientific content. However, when exploring these attitudes it became clear that the real reasons for their choices were not due to a lack of interest about continuous professional education or a perception of it being useless, but how to juggle the limited time that could be put aside by these burdened workers between personal and working life.

This kind of conduct can be understood with a number of different possible explanations.

Lower wages and heavier workloads due to the ongoing global financial crisis may be accountable for the unwillingness of these nurses to invest in post-basic education. For Indian nurses it is very challenging to gain enough money for further education or life-long learning 
because of the need to send remittances to their home country (Mazurenko et al. 2014). In fact, just two of the nurses interviewed had attended post-qualifying courses at a university.

Given the importance of continuous professional development for care quality, more research is needed to understand why Indian nurses in Italy do not pursue additional education once they have satisfied the minimum required levels. Hence, it is vitally important to have orientation courses to support their educational choices and inform them about the possibilities to have advancements in their careers (Kawi \& Xu 2009). Additionally, employer support is also pivotal to ensure that these nurses have access to planned and free or low-priced continuous professional opportunities.

\section{The dimensions of social integration}

The majority of the interviewed nurses were married and brought their families to Italy after their arrival. At first, almost all the Indian nurses planned their migration to be temporary. However, for the greater part of the nurses consulted, this impermanence had become long-term or generally a stable migration and this is in line with the change of immigration patterns noted for Indian nurses by Spetz et al. (2014) and Garner et al. (2015). One of the main reasons to plan to leave Italy or to go back to India was the education of their children. The majority of the Indian nurses expressed feelings of unreliability in the Italian education system. Lectures were only offered in the Italian language, which was considered a main hindrance and a strong reason to move from Italy. To offer their children better perspectives for the future is a dream of many parents and the interviewed nurses believed that Italy, as part of a globalised society, was not a particularly good place to acquire competencies for the international market and the future employment opportunities for their descendants.

The social life of the Indian nurses was mainly associated with their family or the Indian community. The special relationships they could build in parishes or in other meeting places linked 
to the Catholic Church were pivotal. Another important place to socialize with the Italian community was represented by the public libraries, which was related to previous experiences in India and they considered to be part of their cultural heritage.

Their relationships with Italian people were based almost exclusively in the work settings and the relationships with Italians outside the work environment were casual. Building social networks within the Italian society is not straightforward, especially in a country where the public debate on the pros and cons of migration flows is always in the spotlight and sometimes raises anti-immigrant sentiments in parts of the general public.

Socialization takes time, especially among persons who come from very different backgrounds with starkly different cultures, different gender relationships and within different generations. When socialization takes place it opens the world of the migrants to different perspectives and, in our case, strengthened the role of Malayalee women who had experienced a gender role reversal compared to the widespread male-dominated way of living in Kerala (Lum 2012, Johnson et al. 2014, Garner et al. 2015).

\section{Conclusions}

This research can be analyzed for the causes and effects of nurse migration using a push/pull logic, or according to a logic that gives evidence of the concept of brain drain (Li et al. 2014, Garner et al. 2014, Garner et al. 2015, Rao et al. 2011). Yet, if we do not take account of the complex social and political factors where these processes take place, the phenomenon cannot be fully comprehended.

This study states that for Indian nurses in Italy emigration is important to grab the opportunities to expand economic and social privileges, as well as, especially for women, an escape from historical assumptions of stigma associated with nursing work. In fact, women in this on-going 
process of out-migration can redefine themselves in 'family relations where the establishment of a “modern" patriarchy is achieved through women's visibility outside the household' (Gallo 2006: 360). However, it must also be stressed that internationally educated nurse migration leads to a waste of human resources from the contributor countries with economic consequences for the costs sustained by the same countries to educate their health workforce. It is widely accepted that without adequate policy strategies to retain nurses in the donor countries, there will always be shortages and ethical concerns in the services offered (Likupe 2013).

\section{Limitations and strengths}

The idea that the findings should be generalizable is not always the key in qualitative research, and this is more than true in our study for the small sample included. Further work is needed to explore similar issues for Indian nurses living in different parts of Italy, especially in the northern parts, where the working conditions could be better and consequently there could be more professional integration. Without more comprehensive ways to collect data, for example between single interviews and participant observation in the work environments where these immigrant nurses are employed, it is difficult to separate the different meanings of integration.

It is also difficult to explore complicated issues such as the interwoven patterns of nurses' movements without contextualizing them in historical and political-economic relations among countries. Notwithstanding, this is the first study to be carried out on the processes and strategies of immigration of Indian nurses in Italy and the first research that has tried to analyze their professional and social amalgamation in the Italian culture. This project may also hold implications for future comparative research to be carried out in other countries on the practices of emigration of Indian nurses, particularly in other European states. 


\section{Relevance to clinical practice}

If we analyze the phenomenon of out-migration of Indian nurses to Italy it offers opportunities to evaluate the complicated pathways and reasons that go beyond classic migration theories such as push/pull factors. In fact, this study has identified the importance for the nursing profession of investigating the wider socio-cultural complexities that are at the basis of these care transnational flows (Prescott \& Nichter 2014, Walton-Roberts 2015).

Global nurse migration is a pivotal health issue (Prescott \& Nichter 2014) that has to be analyzed having in mind the intertwined textures of the political, economic and social relations and patterns that are continually constructed and re-constructed among different nations and among private and public labour markets. To have more research on the complexities of nurses' movements has become imperative in our globalised world where the working conditions and whereabouts for thousands of health professionals change continuously (Tschudin \& Davis 2008).

\section{References}

Allan H (2016) Ethnocentrism and racism in nursing: reflections on the Brexit vote. Journal of Clinical Nursing, doi: 10.1111/jocn.13627.

Alonso-Garbayo A \& Maben J (2009) Internationally recruited nurses from India and the Philippines in the United Kingdom: the decision to emigrate. Human Resources for Health, 7, 1-11.

Beechinor LA \& Fitzpatrick JJ (2008) Demands of immigration among nurses from Canada and the Philippines. International Journal of Nursing Practice, 14, 178-187.

Blythe J \& Baumann A (2009) Internationally educated nurses: profiling workforce diversity. International Nursing Review 56, 191-197.

Correia T, Dussault G \& Pontes C (2015) The impact of the financial crisis on human resources for health policies in three southern-Europe countries. Health Policy 119, 1600-1605. 
Dicicco-Bloom B (2004) The racial and gendered experiences of immigrant nurses from Kerala, India. Journal of Transcultural Nursing 15, 26-33.

Evans C, Razia R \& Cook E (2013) Building nurse education capacity in India: insights from a faculty development programme in Andhra Pradesh. BMC Nursing, 12( 1), 8.

Fida R, Tramontano C, Paciello M, Kangasniemi M, Sili A, Bobbio A \& Barbaranelli C (2016) Nurse moral disangagement. Nursing Ethics 23, 547-564.

Gallo E (2005) Unorthodox sisters: gender relations and generational change among Malayali migrants in Italy. Indian Journal of Gender Studies 12, 217-250.

Gallo E (2006) Italy is not a good place for men: narratives of places, marriage and masculinity among Malayali migrants. Global Networks 6, 357-372.

Garner SL, Raj L, Prater LS \& Putturaj M (2014) Student nurses' perceived challenges of nursing in India. International Nursing Review 61, 389-397.

Garner SL, Conroy SF \& Gerding Bader S (2015) Nurse migration from India: a literature review. International Journal of Nursing Studies 52, 1879-1890.

Gill R (2011) Nursing shortage in India with special reference to international migration of nurses. Social Medicine 6, 52-59.

Graneheim UH \& Lundman B (2004) Qualitative content analysis in nursing research: concepts, procedures and measures to achieve trustworthiness. Nurse Education Today 24, 105-113.

Humphries N, McAleese S, Matthews A \& Brugha R (2015) 'Emigration is a matter of selfpreservation. The working conditions . . . are killing us slowly': qualitative insights into health professional emigration from Ireland. Human Resources for Health 13:35, doi: 10.1186/s12960015-0022-6

Johnson SE, Green J \& Maben J (2014) A suitable job? A qualitative study of becoming a nurse in the context of a globalizing profession in India. International Journal of Nursing Studies 51, 734 743.

Jose J, Quinn Griffin M, Click ER \& Fitzpatrick JJ (2008) Demands of immigration among Indian nurses who immigrated to the United States. Asian Nursing Research 2, 46-54.

Jose MM (2011) Lived experiences of internationally educated nurses in hospitals in the United States of America. International Nursing Review 58, 123- 129.

Kawi J \& Xu Y (2009) Facilitators and barriers to adjustment of international nurses: an integrative review. International Nursing Review 56, 174-183. 
Kodoth P \& Jacob TK (2013) International mobility of nurses from Kerala (India) to the EU: prospects and challenges with special reference to the Netherlands and Denmark. Working paper 405, Indian Institute of Management Bangalore, 1-69.

Li H, Nie W \& Li J (2014) The benefits and caveats of international nurse migration. International Journal of Nursing Sciences 1, 314-317.

Likupe G (2013) The skills and brain drain what nurses say. Journal of Clinical Nursing 22, 13721381.

Lincoln YS \& Guba EG (1985) Naturalistic inquiry. Newbury Park, CA: Sage.

Lum K (2012) Indian diversities in Italy: Italian case study. CARIM-India Research Study 02. Robert Schuman Centre for Advanced Studies. San Domenico di Fiesole, European University Institute, Italy.

Ma AX, Griffin MT, Capitulo KL \& Fitzpatrick JJ (2010) Demands of immigration among Chinese immigrant nurses. International Journal of Nursing Practice 16, 443-453.

Mazurenko O, Gupte G \& Shan G (2014) A comparison of the education and work experiences of immigrant and the United States of America-trained nurses. International Nursing Review 61, 472478.

Mirza NA, Akhtar-Danesh N, Noesgaard C, Martin L \& Staples E (2014) A concept analysis of abductive reasoning. Journal of Advanced Nursing 70, 1980-1994.

Nair S (2012) Moving with the times: gender status and migration of nurses in India. Routledge, New Delhi.

Percot M (2006) Indian nurses in the Gulf: two generations of female migration, South Asia Research 26, 41-62.

Pittman P, Aiken LH \& Buchan J (2007) International migration of nurses: introduction. Health Service Research 42, 1275-1280.

Polit DF \& Beck CT (2011) Nursing Research, International Edition. Generating and Assessing Evidence for Nursing Practice. 9th edn ISBN 9781451109146. Wolters Kluwer Health/Lippincott Williams \& Wilkins.

Pololi L, Cooper LA \& Carr P (2010) Race, disadvantage and faculty experiences in academic medicine. Journal of General Internal Medicine, 25, 1363-1369.

Prescott M \& Nichter M (2014) Transnational nurse migration: future directions for medical anthropological research. Social Science \& Medicine 107, 113-123.

Price S, Doucet S \& McGillis Hall L (2014) The historical social positioning of nursing and medicine: implications for career choice, early socialization and interprofessional collaboration. Journal of Interprofessional Care 28, 103-109. 
Rao M, Rao K, Kumar A, Chatterjee M \& Sundararaman T (2011) Human resources for health in India. The Lancet 377, 587-598.

Rao MM (2012) Their road to heartache starts at college itself, The Hindu, Bangalore Special Issue. $20^{\text {th }}$ of March.

Rao KD, Ryan M, Shroff Z, Vujicic M, Ramani S \& Berman P (2013) Rural clinician scarcity and job preferences of doctors and nurses in India: a discrete choice experiment. PLOS ONE 8, e82984. http:// dx.doi.org/10.1371/journal.pone.0082984.

Ribeiro JS, Conceição C, Pereira J, Leone C, Mendonça P, Temido M, Vieira CP \& Dussault G (2014) Health professionals moving to... and from Portugal. Health Policy, 114, 97-108.

Rocco G, Affonso DD, Mayberry LJ, Stievano A, Alvaro R \& Sabatino L (2014) The Evolution of Professional Nursing Culture in Italy: Metaphors and Paradoxes. Global Qualitative Nursing Research 1, doi: 10.1177/2333393614549372

Sabatino L, Kangasniemi MK, Rocco G, Alvaro R \& Stievano A (2016) Nurses' perceptions of professional dignity in hospital settings. Nursing Ethics 23, 277-293.

Saldaña J. The coding manual for qualitative researchers. Thousand Oaks: Sage, 2009.

Spetz J, Gates M \& Jones CB (2014) Internationally educated nurses in the United States: Their origins and roles. Nursing Outlook, 62, 8-15.

Timilsina Bhandari KK, Xiao LD \& Belan I (2014) Job satisfaction of overseas-qualified nurses working in Australian hospitals. International Nursing Review 62, 64-74.

Tschudin V \& Davis AJ (2008) The globalisation of nursing. Abingdon: Radcliffe Publishing.

Walton-Roberts M (2012) Contextualizing the global nursing care chain: International migration and the status of nursing in Kerala, India. Global Network 12, 175-194.

Walton-Roberts M (2015) International migration of health professionals and the marketization and privatization of health education in India: From push-pull to global political economy. Social Science \& Medicine 124, 374-382.

Woodbridge M \& Bland M (2010) Supporting Indian nurses migrating to New Zealand: a literature review. International Nursing Review 57, 40-48.

Xiao LD, Willis E \& Jeffers L (2014) Factors affecting the integration of immigrant nurses into the nursing workforce: a double hermeneutic study. International Journal of Nursing Studies, 51 (4), 640-653. 
2

3

4

5
6

7

8

10

11

12

13

14

15

16

17

18

19

20

21

22

23

24

25

26

27

28

29

30

31

32

33

34

35

36

37

38

39

40

41

42

43

44

45

46

47

48

49

50

51

52

53

54

55

56

57

58

59

60

Journal of Clinical Nursing 
Figure 1. Elements that influence Indian nurses' social and professional integration in Italy: summary of the analysis.

\begin{tabular}{|c|c|}
\hline CATEGORIES & THEMES \\
\hline $\begin{array}{l}\text { Out-migrations push-pull } \\
\text { factors }\end{array}$ & \multirow[b]{2}{*}{$\begin{array}{l}\text { Aspects of professional } \\
\text { integration and working } \\
\text { experience }\end{array}$} \\
\hline $\begin{array}{l}\text { Race, color, religion, sex, } \\
\text { national origin } \\
\text { discrimination }\end{array}$ & \\
\hline Good/bad relationships & \multirow{3}{*}{$\begin{array}{l}\text { Intra- and inter- } \\
\text { professional relationships } \\
\text { and perceptions of the } \\
\text { IPASVI Regulatory } \\
\text { Nursing Board }\end{array}$} \\
\hline $\begin{array}{l}\text { Veiled employment } \\
\text { ethnocentrism }\end{array}$ & \\
\hline IPASVI role & \\
\hline $\begin{array}{l}\text { Initial educational } \\
\text { experiences }\end{array}$ & \multirow{2}{*}{$\begin{array}{l}\text { Education and life-long } \\
\text { learning }\end{array}$} \\
\hline $\begin{array}{c}\text { Continuous professional } \\
\text { development }\end{array}$ & \\
\hline $\begin{array}{l}\text { Rapport with the Indian } \\
\text { community }\end{array}$ & Perceptions of social \\
\hline $\begin{array}{l}\text { Social life for their } \\
\text { children }\end{array}$ & \\
\hline
\end{tabular}


Table 1 Participants' characteristics $(\mathrm{n}=20)$.

\begin{tabular}{|c|c|c|c|c|c|c|c|}
\hline Codes & Gender & $\begin{array}{l}\text { Marital } \\
\text { status }\end{array}$ & Age & $\begin{array}{c}\text { Nursing } \\
\text { title }\end{array}$ & $\begin{array}{l}\text { Country where } \\
\text { the nursing title } \\
\text { was obtained }\end{array}$ & Work setting & $\begin{array}{l}\text { Type of working } \\
\text { contract }\end{array}$ \\
\hline I01 & $\mathrm{F}$ & Divorced & $>40$ & Bachelor & Italy & $\begin{array}{l}\text { Nursing home } \\
\text { having an } \\
\text { agreement with the } \\
\text { National Health } \\
\text { Service }\end{array}$ & Permanent contract \\
\hline I02 & M & $\begin{array}{l}\text { Married } \\
\text { with } \\
\text { children }\end{array}$ & $<40$ & Bachelor & India & Nursing home & Permanent contract \\
\hline I03 & $\mathrm{F}$ & Single & $>40$ & Bachelor & Italy & $\begin{array}{l}\text { Nursing home } \\
\text { having an } \\
\text { agreement with the } \\
\text { National Health } \\
\text { Service }\end{array}$ & Permanent contract \\
\hline I04 & $\mathrm{F}$ & $\begin{array}{l}\text { Married } \\
\text { with } \\
\text { children }\end{array}$ & $>50$ & Bachelor & India & $\begin{array}{l}\text { Nursing home } \\
\text { having an } \\
\text { agreement with the } \\
\text { National Health } \\
\text { Service }\end{array}$ & $\begin{array}{l}\text { Independent } \\
\text { worker }\end{array}$ \\
\hline I05 & $\mathrm{F}$ & Single & $>40$ & Bachelor & Italy & $\begin{array}{l}\text { Nursing home } \\
\text { having an } \\
\text { agreement with the } \\
\text { National Health } \\
\text { Service }\end{array}$ & Permanent contract \\
\hline I06 & $\mathrm{F}$ & $\begin{array}{l}\text { Married } \\
\text { with } \\
\text { children }\end{array}$ & $<40$ & Bachelor & India & $\begin{array}{l}\text { Nursing home } \\
\text { having an } \\
\text { agreement with the } \\
\text { National Health } \\
\text { Service }\end{array}$ & Permanent contract \\
\hline I07 & $\mathrm{F}$ & $\begin{array}{l}\text { Married } \\
\text { with } \\
\text { children }\end{array}$ & $>40$ & Bachelor & India & $\begin{array}{l}\text { Nursing home } \\
\text { having an } \\
\text { agreement with the } \\
\text { National Health } \\
\text { Service }\end{array}$ & Permanent contract \\
\hline I08 & $\mathrm{F}$ & $\begin{array}{l}\text { Married } \\
\text { with } \\
\text { children }\end{array}$ & $<40$ & Bachelor & India & $\begin{array}{l}\text { Nursing home } \\
\text { having an } \\
\text { agreement with the } \\
\text { National Health } \\
\text { Service }\end{array}$ & Permanent contract \\
\hline I09 & $\mathrm{F}$ & $\begin{array}{l}\text { Married } \\
\text { with } \\
\text { children }\end{array}$ & 40 & Bachelor & India & $\begin{array}{l}\text { Nursing home } \\
\text { having an } \\
\text { agreement with the } \\
\text { National Health } \\
\text { Service }\end{array}$ & Permanent contract \\
\hline I10 & M & Single & $<30$ & Bachelor & India & $\begin{array}{c}\text { Nursing home } \\
\text { having an } \\
\text { agreement with the } \\
\text { National Health } \\
\text { Service }\end{array}$ & $\begin{array}{l}\text { Fixed-term } \\
\text { contract }\end{array}$ \\
\hline I11 & $\mathrm{F}$ & $\begin{array}{l}\text { Married } \\
\text { with } \\
\text { children }\end{array}$ & $>40$ & Bachelor & India & $\begin{array}{l}\text { Hospital having an } \\
\text { agreement with the } \\
\text { National Health } \\
\text { Service }\end{array}$ & Permanent contract \\
\hline $\mathrm{I} 12$ & $\mathrm{~F}$ & $\begin{array}{l}\text { Married } \\
\text { with } \\
\text { children }\end{array}$ & $>40$ & Bachelor & India & Public hospital & Permanent contract \\
\hline
\end{tabular}




\begin{tabular}{|c|c|c|c|c|c|c|c|}
\hline I13 & $\mathrm{F}$ & $\begin{array}{l}\text { Married } \\
\text { with } \\
\text { children }\end{array}$ & $>60$ & $\begin{array}{l}\text { Nursing } \\
\text { diploma }\end{array}$ & Italy & $\begin{array}{c}\text { Nursing home } \\
\text { having an } \\
\text { agreement with the } \\
\text { National Health } \\
\text { Service }\end{array}$ & Permanent contract \\
\hline I14 & $\mathrm{F}$ & $\begin{array}{c}\text { Married } \\
\text { with } \\
\text { children }\end{array}$ & $>40$ & Bachelor & India & Hospice & Permanent contract \\
\hline I15 & M & $\begin{array}{l}\text { Married } \\
\text { with } \\
\text { children }\end{array}$ & $<40$ & Bachelor & India & $\begin{array}{c}\text { Nursing home } \\
\text { having an } \\
\text { agreement with the } \\
\text { National Health } \\
\text { Service }\end{array}$ & Permanent contract \\
\hline I16 & M & $\begin{array}{c}\text { Married } \\
\text { with } \\
\text { children }\end{array}$ & $<40$ & Bachelor & Italy & Private company & $\begin{array}{c}\text { Independent } \\
\text { worker }\end{array}$ \\
\hline I17 & $\mathrm{M}$ & $\begin{array}{l}\text { Married } \\
\text { with } \\
\text { children }\end{array}$ & 40 & Bachelor & India & $\begin{array}{c}\text { Nursing home } \\
\text { having an } \\
\text { agreement with the } \\
\text { National Health } \\
\text { Service }\end{array}$ & Permanent contract \\
\hline I18 & $\mathrm{M}$ & $\begin{array}{l}\text { Married } \\
\text { with } \\
\text { children }\end{array}$ & $>40$ & Bachelor & India & $\begin{array}{c}\text { Nursing home } \\
\text { having an } \\
\text { agreement with the } \\
\text { National Health } \\
\text { Service }\end{array}$ & Permanent contract \\
\hline I19 & $\mathrm{F}$ & $\begin{array}{l}\text { Married } \\
\text { with } \\
\text { children }\end{array}$ & $<39$ & Bachelor & India & $\begin{array}{c}\text { Nursing home } \\
\text { having an } \\
\text { agreement with the } \\
\text { National Health } \\
\text { Service }\end{array}$ & Permanent contract \\
\hline $\mathrm{I} 20$ & M & $\begin{array}{l}\text { Spoused } \\
\text { with } \\
\text { children }\end{array}$ & 50 & Bachelor & Italy & Public hospital & $\begin{array}{l}\text { Fixed-term } \\
\text { contract }\end{array}$ \\
\hline
\end{tabular}


Table 2 Nurses registered at the Ipasvi Regulatory Nursing Board of Rome at December 2015.

\begin{tabular}{|c|c|c|c|c|c|}
\hline Country & $N$. & $\%$ & Country & $N$. & $\%$ \\
\hline Romania & 1.677 & 36,3 & Colombia & 23 & 0,5 \\
\hline India & 892 & 19,4 & Brazil & 22 & 0,4 \\
\hline Albania & 435 & 9,4 & Ecuador & 22 & 0,4 \\
\hline Poland & 430 & 9,3 & Burkina Faso & 20 & 0,4 \\
\hline Peru & 214 & 4,6 & Serbia & 16 & 0,3 \\
\hline Philippines & 128 & 2,7 & Tunisia & 15 & 0,3 \\
\hline Spain & 80 & 1,7 & France & 15 & 0,3 \\
\hline Ukraine & 69 & 1,5 & Portugal & 12 & 0,2 \\
\hline Moldava & 65 & 1,4 & Slovakia & 10 & 0,2 \\
\hline Bulgaria & 43 & 0,9 & Cuba & 9 & 0,2 \\
\hline Germany & 40 & 0,8 & Ethiopia & 9 & 0,2 \\
\hline Republic of Congo & 36 & 0,7 & Morocco & 9 & 0,2 \\
\hline Argentina & 30 & 0,6 & Iran & 9 & 0,2 \\
\hline Nigeria & 28 & 0,6 & Great Britain and Northern Ireland & 7 & 0,1 \\
\hline Cameroon & 26 & 0,5 & Other countries & 174 & 3,5 \\
\hline Madagascar & 26 & 0,5 & Total & 4.591 & 100,0 \\
\hline & & & & & \\
\hline
\end{tabular}




\section{What does this article contribute to the wider global clinical community?}

- In the context of global mobility, the interpretation of the professional experiences of internationally educated nurses is complex and has to be seen against the backdrop of socioeconomic and political patterns that are constantly constructed and re-constructed worldwide.

- While out-migration of nurses from India has been explored in some countries, there is a gap in understanding this phenomenon in Europe, particularly in Southern European countries. Studies on nurse mobility are pivotal to comprehend the emerging flux of nurses to and from these countries in the ever-changing and dynamically interwoven societies.

- The current transformations in Indian nurse migration to Italy is new. In this study, through indepth interviews, Indian nurses' professional integration in the Italian nursing workforce and in the Italian social environment was analyzed. The study of Indian nurses in Italy shows that their professional integration and cultural socialization is not straightforward for different cultural variables. 